\title{
THE RELATIVE EFFECT OF LIME AS OXIDE AND CARBONATE ON CERTAIN SOILS.
}

\author{
BY HENRY BROUGHAM HUTCHINSON AND \\ KENNETH MACLENNAN \\ (Carnegie Research Scholar). \\ (Lawes Agricultural Trust, Rothamsted Experimental Station.) \\ Received March 26th, 1914.
}

IN an earlier communication by one of us (1) an account was given of some preliminary experiments on the action of caustic lime on the soil, with particular reforence to the phenomena of partial sterilisation.

From the prantical standpoint the question is of considerable importance, inasmuch as an effective sterilising agent for usc in intensive field cultivation has yet to be found. Caustic limc, however, has other effects: it is used for promoting more rapid decay, thus ensuring a quicker circulation of foodstuff's in the soil, and employed for clestroying soil pests and for "sweetening" soil. Little, however, is known of the mechanisms of these changes, and the present extended investigation was undertaken to study the subject from a broader point of view.

Schulze in 1846 (2) found that in application of caustic lime to a humus soil accelerated the consumption of oxygen and the production of carbon dioxide in a marked regree. Similinr results were recorded by Peterson (3) and at a later date and with reference to carbonate, by Eberminyer (4) and also Hilgard (5), while the effect of caustic lime in destroying organic matter of the soil has been demonstraterl by Wheeler, Sargent and Hartwell (6) amongst others. Boussingault observed that the conversion of unavailable nitrogen to ammonia was greatly facilitaterl by applications of lime, while the production of nitrates was inhibited. The type of action on micro-organic growth in 


\section{H. B. Hutchinson and K. MacLennan}

the soil depends largely on the compound added. Calcium oxide not only neutralises soil acidity but also appears to break down some organic compounds and increases the anount of compounds easily resolved into ammonia or capable of serving as food for bacteria. Calcium carbonate, on the other hand, appears only to neutralise acid soil compounds and not to decompose the complex organic residues. This difference nccounts for many of the experimental results obtained.

Chester (7) records increases in the number of organisms in certain limed soils, and concludes that this effect was not due to any direct action of the lime but to the more favourable reaction induced in the soil. In field experiments by Fabricius and von Feilitzen (8) an application of lime greatly increased the number of bacteria in moor soils, those in their natural condition containing only relatively few organisms.

Engberding (9) records a temporary rise in the numbers of bacteria following treatment of a soil with 0.1 per cent. calcium oxide. This is in accordance with the results already recorded by us.

Fischer (10) added lime to soils and observed first an appreciable initial depression in the numbers of bacteria and then a rapid rise to very high numbers. This was regarded by the author as a pure stimulation effect, although we consider it was due to the production of available food stuffs by the lime.

Wolf (11) observed the favourable effect of lime on the production of nitrates, and this was confirmed at a later date by Peterson (3) and numerous others. The increased availability of certain fertilisers as the result of liming has been shown to be effected with raw bone by Jenkins and Britton (12) and with dried blood, cotton seed meal and other organic residues by Withers and Fraps (13).

The effect of certain additions of lime on nitrification as also on nitrogen fixation, etc., has been further demonstrated. Wohltmann, Fischer and Schneider (14), examining field soils which had been limed, found that the amount of nitrate and the available potash and phosphate were increased in consequence.

The importance of the presence of lime in the soil for nitrogen fixation has been shown by Ashby, working in this laboratory, who found that a deficiency in this soil constituent led to a decrease in nitrogen-fixing powers, while the susceptibility of the free-living nitrogen-fixing organism Azotobacter has been suggested as a test for the presence of alkaline carbonates or calcium carbonate in the soil (15). The function of lime in increasing the biochemical efficiency 
of bacteria has been demonstrated in numerous instances by means of the Remy-Löhnis method, and work on these lines has indicated an improvement in soil conditions for such processes as peptone decomposition, nitrification and nitrogen fixation (16).

In the earlier paper, to which reference has already been made, it was shown that lime in the caustic state exerted in common with other mild antiseptics a specific action by disturbing the biological equilibrium in the soil. As a result of this, certain classes of protozoa, in common with the nitrifying bacteria, were destroyed by heavy applications of lime; after an initial depression, the total numbers of bacteria growing on gelatine plates were subsequently largely increased, and led to corresponding increments of ammonia, and, in pot experiments, of plant growth. In continuation of this work we have attempted to determine the amount of lime required to induce partial sterilisation, and the relative values of calcium oxide and carbonate in other and acid soils, and further, to determine the general character of the changes set up in each case.

\section{EXPERIMENTAL.}

The investigations were carried out with five soils of widely different types. Their general characters are detailed below and, in some cases, information as to their behaviour towards lime under field conditions is available.

1. Rothamsted Soil. This is a poor unmanured soil from the paths on Hoos Field, it is a stiff clay loam overlying chalk and containing $2 \cdot 22$ per cent. carbonate.

2. Chelsea Soil. From the Physic Gardens, Chelsea, S.W. This soil was originally Thames Sand, but by heavy applications of stable manure for many generations and by deposition of soot it has become highly organic in character and black in colour.

3. Craibstone Soil. From the Experimental Farm of the North of Scotland College of Agriculture. It is a light sandy organic soil deficient in carbonate but regarded as being comparatively fertile.

4. Millbrogk Soil. From a portion of the Woburn Experimental Fruit Farm. It is a very light sandy soil, low in organic matter, and was selected on this account to indicate how far injurious results might attend heavy dressings of caustic lime.

5. Woburn Soil. From the Woburn Experimental Station of the Royal Agricultural Society. The soil is an open sandy loam, and has 
been rendered distinctly acid by annual applications of sulphate of ammonia for the last 37 years. This acidity is so pronounced in the field as to check the growth of wheat and barley but not of oats.

TABLE I. Shouning the percentuges of organic matter, nitrogen, etc., in the vurious souls.

\begin{tabular}{|c|c|c|c|c|c|c|c|}
\hline & & $\begin{array}{l}\text { Loss on } \\
\text { ignition }\end{array}$ & Nitrogen & $\begin{array}{l}\text { Carbonate } \\
\text { as } \mathrm{CaCO}_{3}\end{array}$ & $\mathrm{CaO}$ & $\mathrm{MgO}$ & Clay \\
\hline $\begin{array}{l}\text { Rothamste } \\
\text { Millbrook } \\
\text { Chelsea } \\
\text { Craibstone } \\
\text { Woburn }\end{array}$ & $\begin{array}{c}\text { Soil } \\
\text { " } \\
" 1 \\
" 1\end{array}$ & $\begin{array}{r}7.72 \\
: \quad 4.46 \\
14.32 \\
14.55 \\
4.58\end{array}$ & $\begin{array}{l}0.133 \\
0.085 \\
0.455 \\
0.316 \\
0.117\end{array}$ & $\begin{array}{r}2.66 \\
0.03 \\
0.89 \\
\text { none } \\
\text { none }\end{array}$ & $\begin{array}{l}1.94 \\
0.26 \\
1.42 \\
0.41 \\
0.56\end{array}$ & $\begin{array}{l}0.21 \\
0.15 \\
0.17 \\
0.22 \\
0.15\end{array}$ & $\begin{array}{l}1.39 \\
0.59 \\
0.63 \\
0.42 \\
0.63\end{array}$ \\
\hline
\end{tabular}

In order that the changes following treatment might be determined as closely as possible, monthly examinations of the various soils were carried out. The numbers of bacteria were ascertained by the gelatine plate method, and the presence of protozoa tested by inoculation of a sample of each soil into hay infusion. Free ammonia in the soils was estimated by the method described by Russell ${ }^{1}$ and the nitrates determined after reduction by the zinc-copper couple.

Before treatment all the soils were passed through a $3 \mathrm{~mm}$. sieve and filled into bottles in lots of $900 \mathrm{grms}$. A set of bottles from each soil was set aside as control, and the others received calcium oxide in the proportion of $0.1,0.2,0.3,0.4,0.5$ and 1.0 per cent., while calcium carbonate was added to another lot to the extent of 1 per cent., with the exception of the Craibstone soil, where applications of $0.3,0.6$, 0.9 per cent. of carbonate were made. The water content was made up, by means of sterilised water, to 18 per cent. A set of bottles was taken immediately after the end of this ten day treatment, and the others were stored provided with cotton wool plugs at room temperature.

\section{Rothamsted Soil.}

As shown above, this soil already contained sufficient calcium carbonate for normal growth, and further additions fail to induce any change in bacterial growth, production of plant food, or weight of crop. All the applications of quicklime, with the exception of $0 \cdot 1$ per cent., caused an initial depression in the numbers of bacteria. In the case of the lightest application the bacteria rose within the first ten days from 
23 to 37 millions, and then decreased gradually to the level in the untreated soil. Thirty days afterwards the bacteria in the soil receiving 0.2 per cent. calcium oxide had risen to 166 millions and then began to decrease. Somewhat similar changes occurred in the soils receiving heavier dressings, and in general the heavier the application the greater is the initial depression in bacterial numbers, and the longer the period before the numbers for each particular dressing attain a maximum. The soil receiving 1.0 per cent. of caustic lime showed no material increase in numbers even after 120 days. Further, the addition of a fairly large quantity of carbonate failed to affect the bacterial numbers. The high numbers obtained with some of these soils, for instance after 90 days with 0.5 per cent. of calcium oxide, were chiefly a yellow micro-coccus, which disappeared within a short time and presumably flourished on some of the decomposition products resulting from the action of the lime on the soil.

The direct chemical action of the lime results in an immediate increase in the amount of free ammonia, and especially in the case of the heaviest dressing, where during the period of bacterial inaction the amount of ammonia increased from 3 to 24 parts per million, whilst when the bacteria were active it rose from 24 to 92 parts per million. The very high bacterial numbers observed after 90 days are not, however, associated with any corresponding increase of ammonia; indeed, where 0.5 per cent. of lime was added, no increase was obtained between the 40th and the 120th day. Initial inhibition of nitritication is apparent with dressings above 0.1 per cent. calcium oxide, and permanent inhibition with 0.4 per cent. Tests for protozoa showed the presence of some of the larger forms in the control, and the two soils receiving the lower applications of lime. After 40 days they appeared in soil receiving 0.3 per cent. and were absent from the soils receiving heavier doses, while present in that receiving carbonate.

These two facts indicate that the partial sterilisation effect is produced by dressings of 0.3 per cent. or more calcium oxide. But where a solid and non-volatile antiseptic is employed it is difficult to discriminate sharply between the partial sterilisation and other effects.

\section{Millbrook Soil.}

This light sandy soil exhibits a greater sensitiveness towards relatively small applications of caustic lime than the Rothamsted soil. Not only is the initial depression in bacterial numbers greater, but the effect appears to persist longer. With the lighter doses such as $0 \cdot 1$ and 
H. B. Hutchinson and K. MacLennan

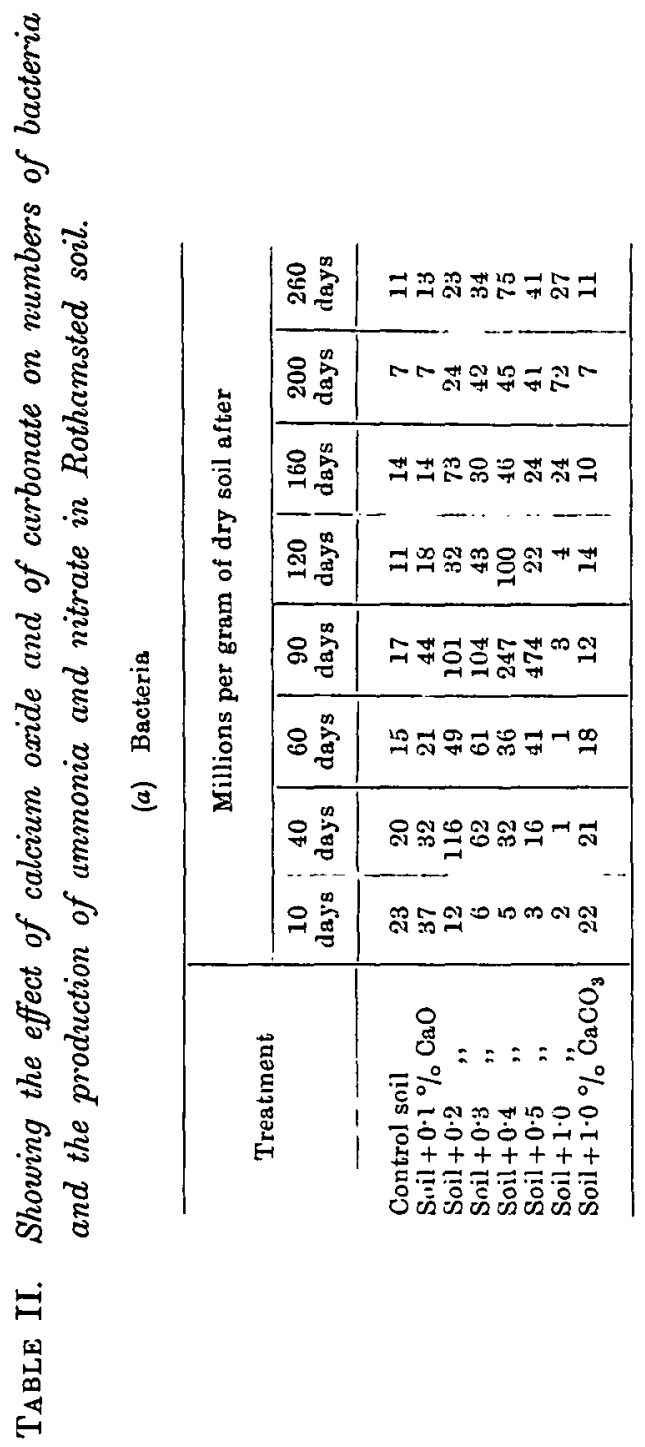

\begin{tabular}{|c|c|c|c|}
\hline \multicolumn{3}{|c|}{ 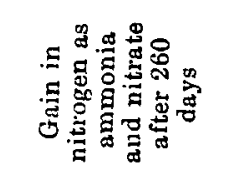 } & 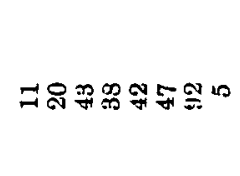 \\
\hline \multirow{14}{*}{ 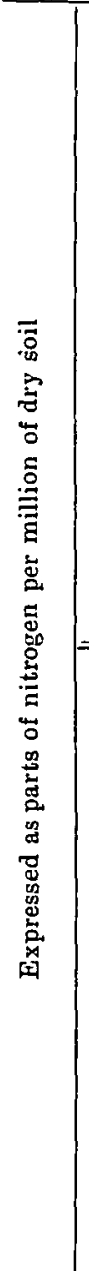 } & \multirow{7}{*}{ 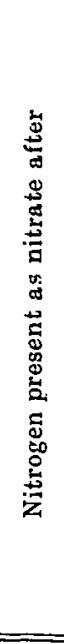 } & 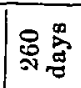 & 구요 \\
\hline & & \& & 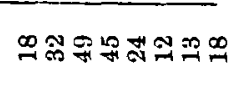 \\
\hline & & $\underset{\pi}{\stackrel{\infty}{m}}$ & $\Xi ゚$ \\
\hline & & ه & 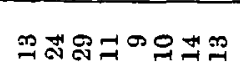 \\
\hline & & $: \stackrel{0}{\sharp}$ & 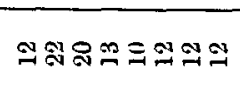 \\
\hline & & \& & 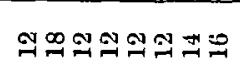 \\
\hline & & ᄋ & $\exists=9^{\circ} \approx z=$ \\
\hline & \multirow{7}{*}{ 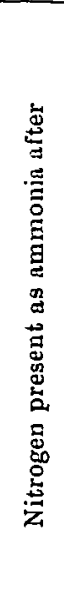 } & $\stackrel{0}{0}$ & 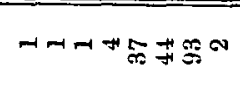 \\
\hline & & \& & m n m n \\
\hline & & 量 & " \\
\hline & & $8 \stackrel{0}{\circ}$ & 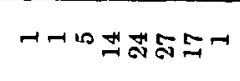 \\
\hline & & $8 \stackrel{0}{0}$ & 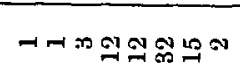 \\
\hline & & 웧 & N \\
\hline & & 용 & N \\
\hline \multicolumn{3}{|c|}{ 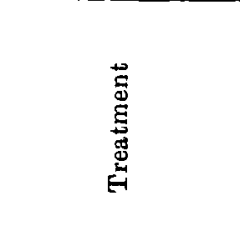 } & 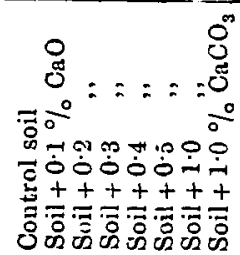 \\
\hline
\end{tabular}


0.2 per cent. calcium oxide, however, there is a quick recovery within the first 10 days, and the bacterial content rises to about 77 million. This we suppose to be due to a temporary feeding effect, as is also the high content observed at the end of 30 days with the 0.3 per cent. application. The application of carbonate to this soil, comparatively poor in lime, is not followed by any appreciable increase in the numbers of bacteria for the first few months, although the production of nitrates appears to be increased slightly.

The initial amount of ammonia produced by the action of $0 \cdot 1$ per cent. calcium oxide was almost completely nitrified within the first month, whilst the effect of 0.2 per cent. persisted for a month longer. A greater retardation by 0.3 per cent. persisted up to four months, and at the end of this time nitrification set in. All larger dressings completely inhibited the process; in fact a slight loss of nitrate seems to have occurred. As already pointed out, the effect of the carbonate is slight but definite. Examinations for protozoa after 30 days showed the absence of ciliates from all the soils receiving more than 0.2 per cent. calcium oxide, and of all forms when 0.5 and 1 per cent. were given.

\section{Chelsea Soil.}

As compared with the behaviour of the two foregoing poor soils, that of rich soils such as Chelsea, containing an abundance of carbonate, or Craibstone, deficient in carbonate, is very striking. Table IV shows that even the heaviest application of calcium oxide failed to reduce the numbers of bacteria to any great extent in the Chelsea soil. The numbers show considerable variation, but in general they increase up to about 70 days, and then steadily fall off. Finally, after 10 months, they are roughly proportional to the amount of caustic lime applied. Carbonate had little or no effect. No permanent depression of nitrification occurred, the heavy application of 1.0 per cent. calcium oxide only checked it for the period of 130 days. However, examinations for protozoa immediately after treatment failed to reveal the presence of ciliated protozoa in the soils receiving 0.5 and 1.0 per cent. calcium oxide, but after 130 days fiagellates only were found in the latter soil, indicating that about this point some measure of partial sterilisation had occurred. In the case of this soil, as in the two preceding ones, we find the usual equal sensitiveness of nitrifying bacteria and of the higher protozoa towards treatment. 


\section{H. B. Hutchinson and K. Maclennan}

TABLE III. Showing the effect of calcium oxide and of carbonate on numbers of bacteria and the production of ammonia and nitrate in Millbrook soil.

(a) Bacteria

\begin{tabular}{|c|c|c|c|c|c|}
\hline \multirow{2}{*}{ Treatment } & \multicolumn{5}{|c|}{ Millions per gram of dry soil after } \\
\hline & $\begin{array}{l}10 . \\
\text { days }\end{array}$ & $\begin{array}{c}30 \\
\text { days }\end{array}$ & $\begin{array}{c}70 \\
\text { days }\end{array}$ & $\begin{array}{l}100 \\
\text { days }\end{array}$ & $\begin{array}{c}130 \\
\text { days }\end{array}$ \\
\hline $\begin{array}{l}\text { Control soil } \\
\text { Soil }+0.1 \% \mathrm{CaO} \\
\text { Soil }+02 \% \\
\text { Soil }+0.3 \quad " \\
\text { Soil }+0.4 \quad " \\
\text { Soil }+0.5 \quad " \\
\text { Soil }+1.0 \% " \\
\text { Soil }+1.0 \% \mathrm{CaCO}_{3}\end{array}$ & $\begin{array}{c}14 \\
57 \\
77 \\
3 \\
1 \\
1 \\
14\end{array}$ & $\begin{array}{r}11 \\
33 \\
84 \\
481 \\
66 \\
\cdot 4 \\
\cdot 1 \\
14\end{array}$ & $\begin{array}{r}10 \\
30 \\
114 \\
107 \\
98 \\
- \\
10\end{array}$ & $\begin{array}{r}9 \\
22 \\
35 \\
58 \\
29 \\
30 \\
21 \\
10\end{array}$ & $\begin{array}{r}9 \\
19 \\
23 \\
78 \\
98 \\
-5 \\
12\end{array}$ \\
\hline
\end{tabular}

(b) Ammonia and Nitrate

\begin{tabular}{|c|c|c|c|c|c|c|c|c|c|c|c|}
\hline \multirow{3}{*}{ Treatment } & \multicolumn{10}{|c|}{ Expressed as parts of nitrogen per million of dry soil } & \multirow{3}{*}{$\begin{array}{l}\text { Gain in } \\
\text { nitrogen as } \\
\text { ammonia } \\
\text { and nitrate } \\
\text { after } 130 \\
\text { days }\end{array}$} \\
\hline & \multicolumn{5}{|c|}{ Nitrogen present as ammonia after } & \multicolumn{5}{|c|}{ Nitrogen present as nitrate after } & \\
\hline & $\begin{array}{c}10 \\
\text { days }\end{array}$ & $\begin{array}{c}30 \\
\text { days }\end{array}$ & $\begin{array}{c}70 \\
\text { days }\end{array}$ & $\begin{array}{c}100 \\
\text { days }\end{array}$ & $\begin{array}{c}130 \\
\text { days }\end{array}$ & $\begin{array}{c}10 \\
\text { days }\end{array}$ & $\begin{array}{c}30 \\
\text { days }\end{array}$ & $\begin{array}{c}70 \\
\text { days }\end{array}$ & $\begin{array}{c}100 \\
\text { days }\end{array}$ & $\begin{array}{c}130 \\
\text { days }\end{array}$ & \\
\hline 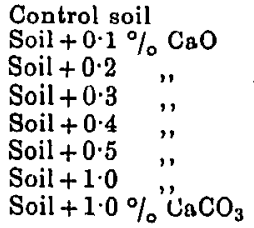 & $\begin{array}{r}2 \\
7 \\
12 \\
10 \\
10 \\
11 \\
17 \\
2\end{array}$ & $\begin{array}{r}1 \\
1 \\
13 \\
16 \\
14 \\
12 \\
13 \\
1\end{array}$ & $\begin{array}{r}4 \\
4 \\
5 \\
30 \\
36 \\
35 \\
19 \\
4\end{array}$ & $\begin{array}{r}3 \\
3 \\
4 \\
28 \\
48 \\
53 \\
28 \\
3\end{array}$ & $\begin{array}{r}2 \\
1 \\
2 \\
7 \\
\mathbf{4 5} \\
53 \\
52 \\
2\end{array}$ & $\begin{array}{r}9 \\
11 \\
9 \\
10 \\
12 \\
9 \\
10 \\
9\end{array}$ & $\begin{array}{l}10 \\
19 \\
10 \\
10 \\
10 \\
10 \\
11 \\
10\end{array}$ & $\begin{array}{r}12 \\
19 \\
31 \\
8 \\
8 \\
10 \\
13 \\
17\end{array}$ & $\begin{array}{r}\overline{19} \\
38 \\
19 \\
8 \\
15 \\
17\end{array}$ & $\begin{array}{r}13 \\
28 \\
38 \\
36 \\
6 \\
6 \\
8 \\
20\end{array}$ & $\begin{array}{r}4 \\
18 \\
29 \\
32 \\
40 \\
48 \\
49 \\
11\end{array}$ \\
\hline
\end{tabular}

\section{Craibstone Soil.}

In some respects this soil resembles that from Chelsea; both are light, rich in organic matter, and poor in clay, but while the Chelsea soil contains upwards of 1.0 per cent. calcium carbonate the Craibstone soil contains very little.

The remarkable difference is that the smaller applications of lime do not appreciably affect the bacterial numbers, and 1.0 per cent. caused only a small initial depression, which persists for a short period only. In no instance are such high counts recorded as with other soils, and any depression of the higher protozoa appears to pass off within the 
first few weeks after treatment. The addition of various amounts of calcium carbonate ${ }^{1}$ failed to induce increased growth of bacteria, presumably because there was no disturbance of the equilibrium between these and other organisms. The total flora, on the other hand, appeared to function more efficiently, and there was a greatly increased nitrate production.

The amount of ammonia produced immediately after treatment is not very great, and it usually disappears within 40 days. Only in the case of the 1.0 per cent. oxide application is there any accumulation of ammonia, and this begins to disappear after about 80 days. In spite of the low carbonate content of the untreated soil, nitrification is active from the very first, but is decidedly accelerated by all the lime applications. The relative return of nitrates for equivalent amounts of calcium or oxide of carbonate would appear to be greater with the former within the first 170 days; between this and 380 days the difference becomes eliminated.

\section{Woburn Soil.}

The Woburn soil stands out in striking contrast to these. As a result of its previous annual applications of ammonium sulphate it has been depleted of all carbonate, and possesses a well-marked acid reaction.

Table VI shows that no depression in bacterial numbers is produced at the end of 10 days excepting in the soil receiving 1.0 per cent. calcium oxide. The results suggest an almost immediate absorption of all the lower doses of caustic lime, and simultaneous access to nutrients hitherto held out of action by adverse conditions. The application of 0.1 per cent. calcium oxide has sufficed to suspend temporarily the action of these conditions, but at the end of 200 days there is a return in numbers to the level of those in the control soil. The larger dressings apparently give rise to a feeding effect, and very high numbers (906 millions) are obtained after 90 days with soil 0.4 per cent. $\mathrm{CaO}$. Furthermore, the occurrence of greater numbers of bacteria in this soil than in that receiving 0.5 per cent. is due no doubt to the extinction of less resistant but more actively growing bacteria in the latter ${ }^{2}$. With

1 With this soil the scheme of experiment was varied by applying three different weights of colcium carbonate for purposes of comparison with the caustic lime.

2 This would appear to constitute a parallel with effects observed in other work. Treatment of a soil with toluene serves to kill off certain species of bacteria, which when reintroduced to a treated soil give much higher numbers than are observed in tolnened soils not reinfected. 
H. B. Hutchinson and K. Maclennan

311
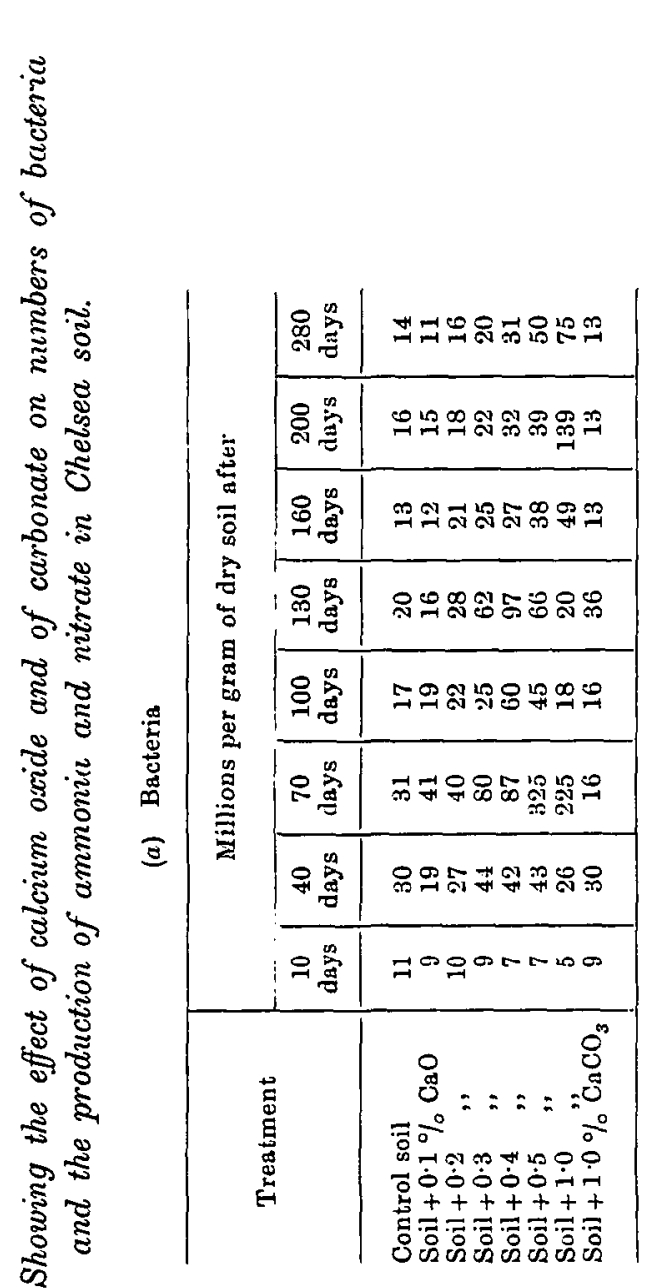

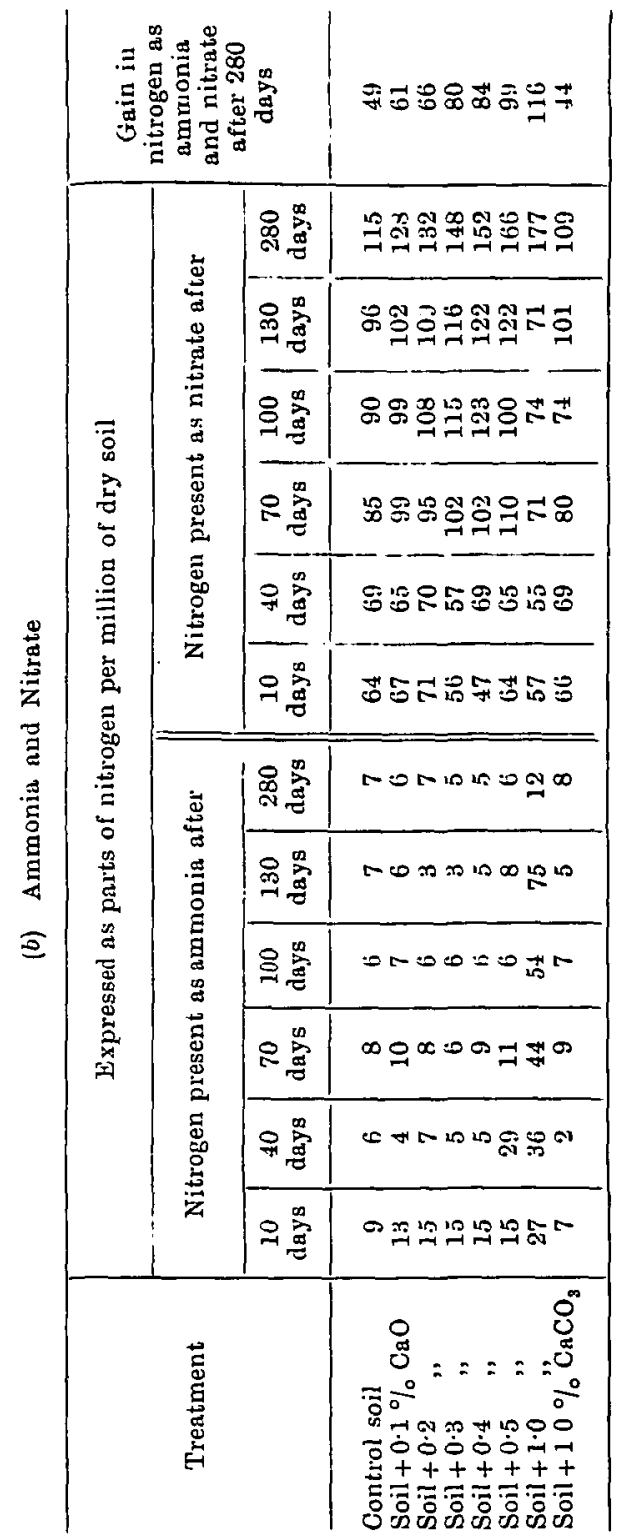


the heaviest dressing of caustic lime the depression in numbers persists for upwards of 150 days, but then a progressive increase occurs at least up to the end of 300 days.

The data obtained from the determinations of ammonia are interesting. The initial amount of ammonia is high on account of previous treatment and the acidity of the soil, but in spite of this a slow change to nitrate occurs as well as additional breakdown processes, since the ammonia is reduced by 9 parts per million and the total production

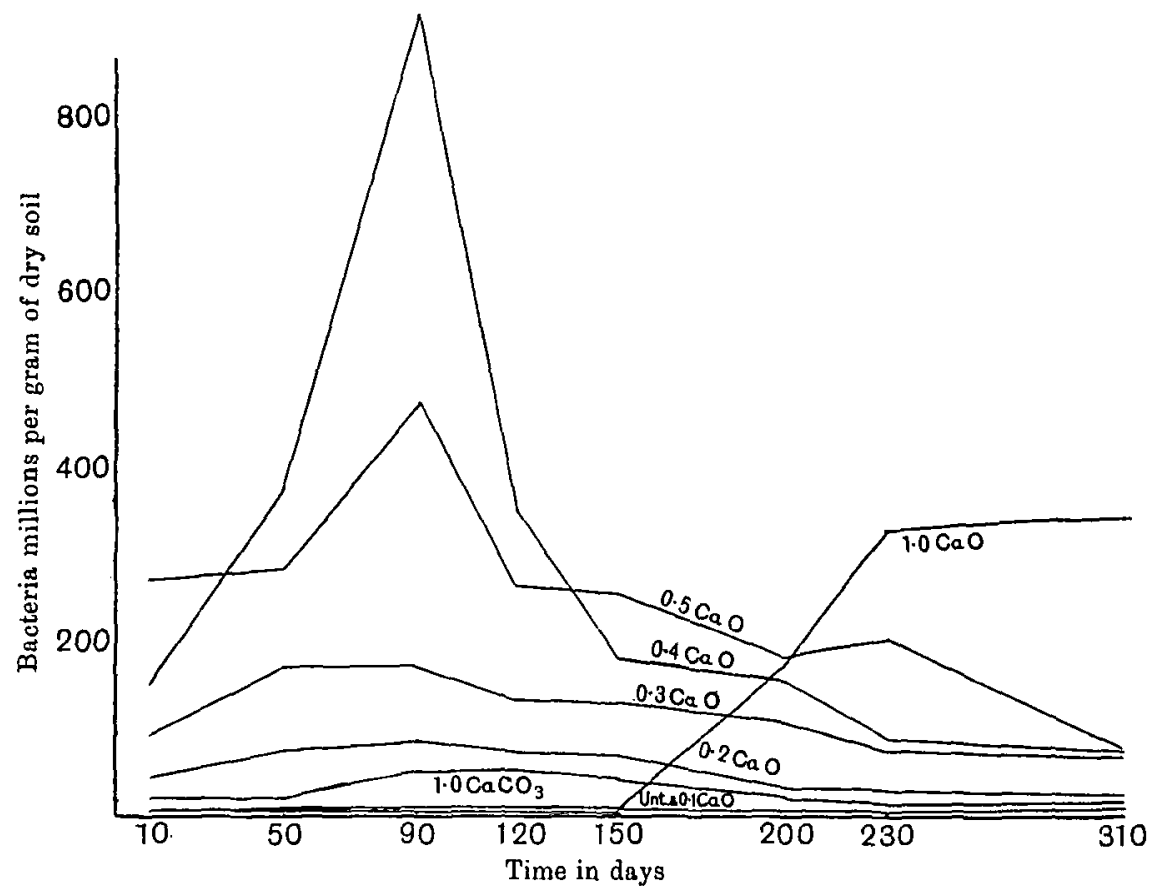

Curve 1. Bacterial numbers in Woburn soil.

of ammonia and nitrate is increased by 40 parts. Small quantities of caustic lime or of carbonate bring about a rapid decrease in the amount of free ammonia, but larger quantities do not. Only the heaviest dressing, however, retarded the change for any considerable time. The total gain in nitrogen, as ammonia and nitrate, is much greater per increment of 0.1 per cent. calcium oxide than in any of the other soils. Ciliates, amoebae and flagellates were found in all the soils excepting that receiving $\mathbf{1 . 0}$ per cent. calcium oxide, in which arnoebae only were found after 10 days, but at all subsequent examinations only flagellates appeared. Here again parallelism between disappearance of protozoa and of nitrifying organisms occurs. 
H. B. Hut'hinson and K. MacLennan

\begin{tabular}{|c|c|c|c|}
\hline \multicolumn{3}{|c|}{ 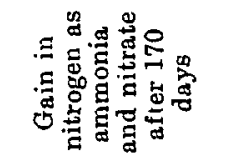 } & \multirow{2}{*}{ 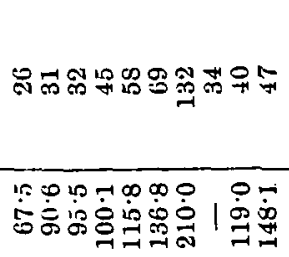 } \\
\hline \multirow{13}{*}{ 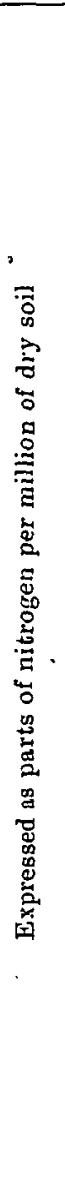 } & \multirow{7}{*}{ 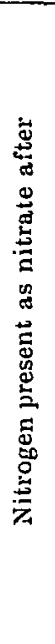 } & 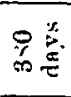 & \\
\hline & & 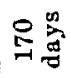 & 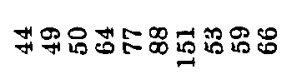 \\
\hline & & $\underset{ }{*}$ & 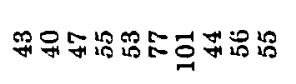 \\
\hline & & 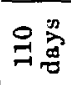 & 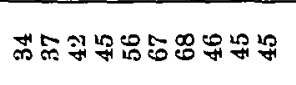 \\
\hline & & $\infty \stackrel{\infty}{\frac{\infty}{x}}$ & 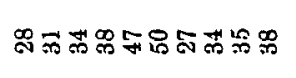 \\
\hline & & 윤 & 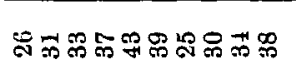 \\
\hline & & 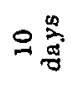 & 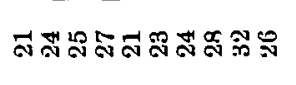 \\
\hline & \multirow{6}{*}{ 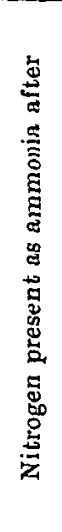 } & 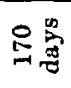 & 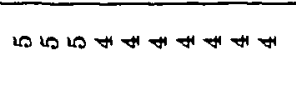 \\
\hline & & 㐘窎 & 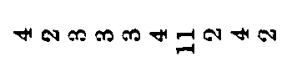 \\
\hline & & 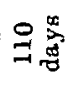 & 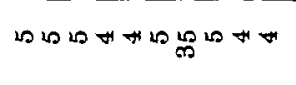 \\
\hline & & 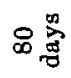 & 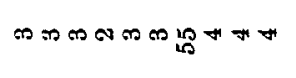 \\
\hline & & 유 & 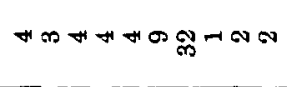 \\
\hline & & $\varrho \overbrace{\frac{\pi}{2}}^{\infty}$ & এルー \\
\hline & 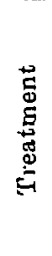 & & 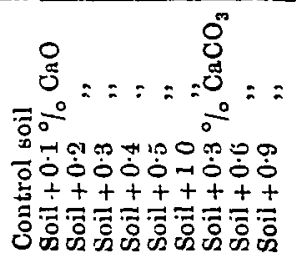 \\
\hline
\end{tabular}


Reviewing the foregoing results, it is obvious that the addition of caustic lime to these soils exercised a marked effect on the growth of putrefactive and nitrifying organisms and on soil protozoa. This action leads to a simplification of the soil flora, and in some cases is sufficient to alter the character of the nitrogen compounds available as food for plants, ammonia production being increased and that of nitrates depressed in the primary stages of growth. The increases in total

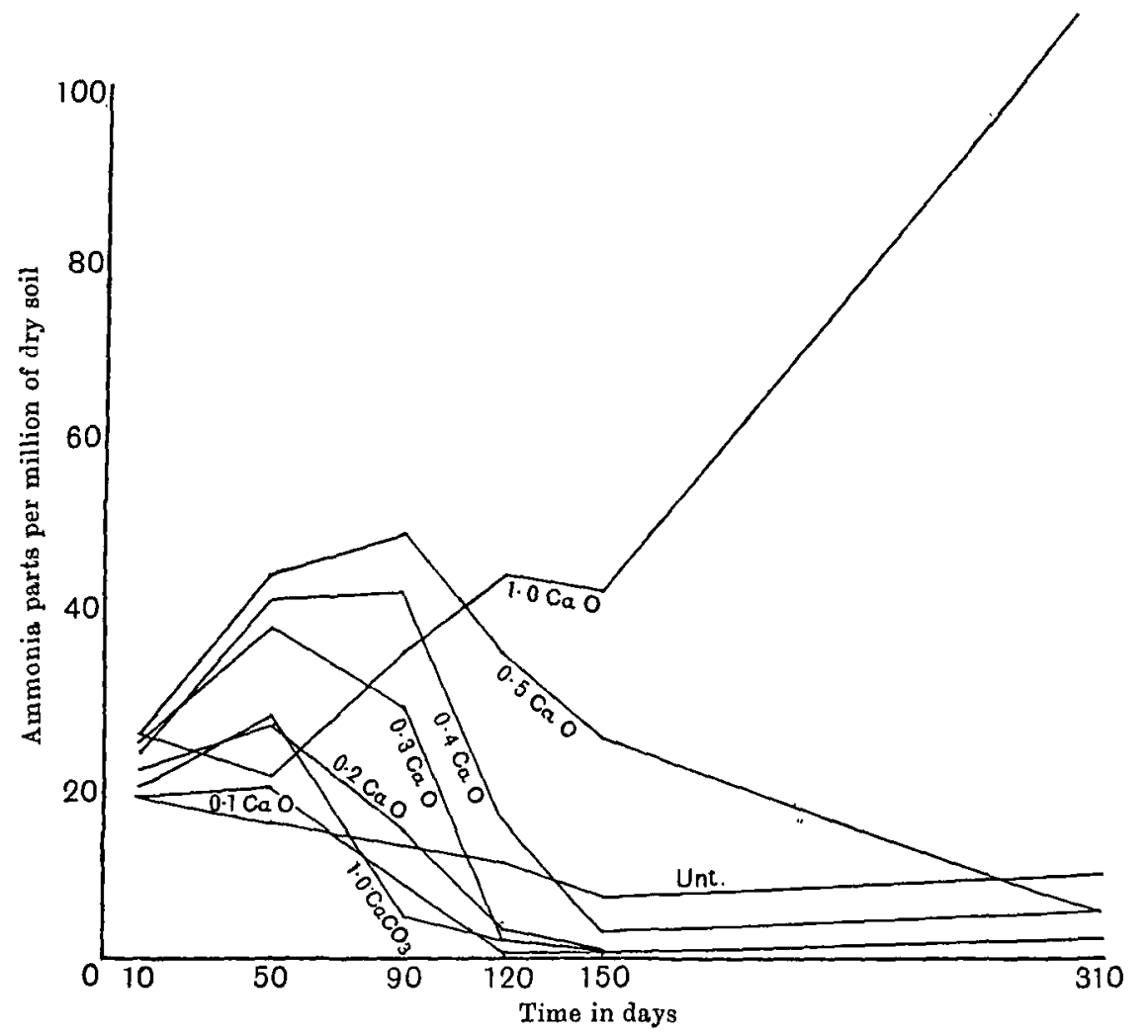

Curve 2. Ammonia production in Woburn soil.

ammonia and nitrates for each increment of lime show a certain proportionality with the amount applied, but this varies with the character of the reserves of soil nitrogen and the comparative poverty of the soil in carbonate. The Woburn soil is typical of the first case, where considerable reserves are liberated on the application of small doses of lime; with the Craibstone soil the lime is directly absorbed by the soil, and the comparative returns are low. It may be stated, however, as a general average, that the relative return of nitrogen in a form 
H. B. Hutchinson and K. MacLennan

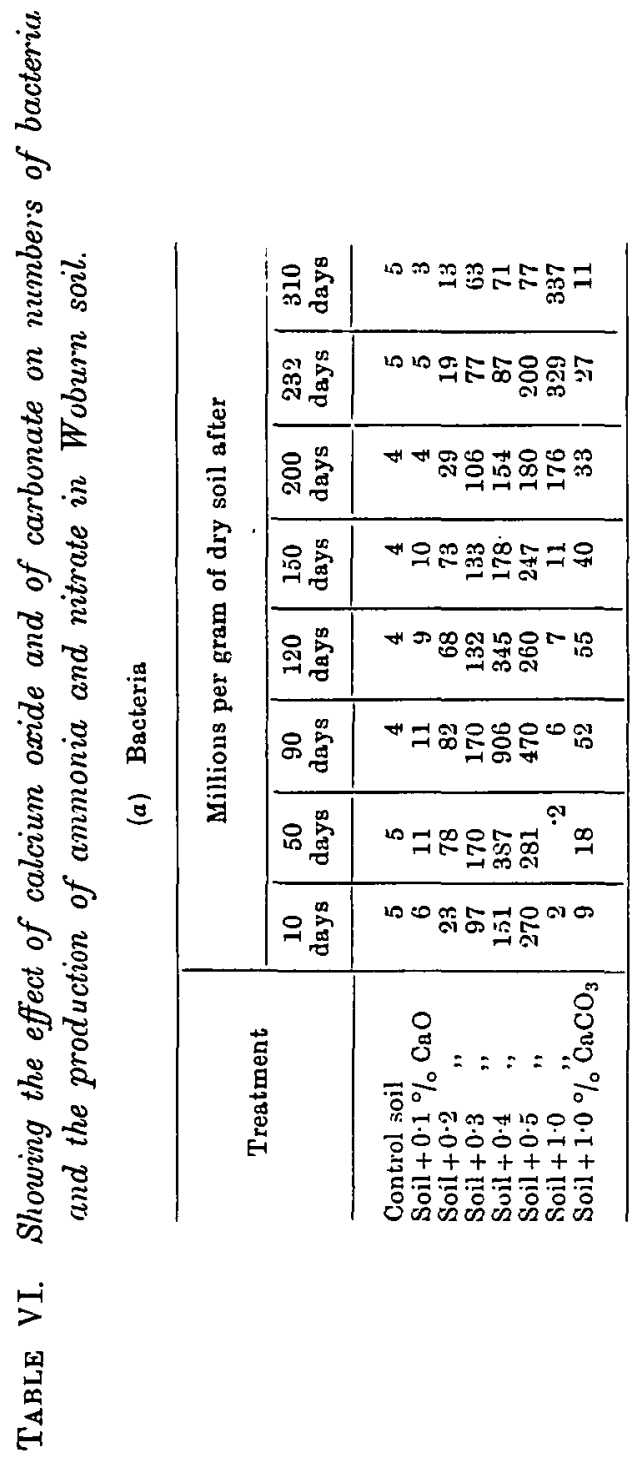

\begin{tabular}{|c|c|c|c|}
\hline \multicolumn{3}{|c|}{ 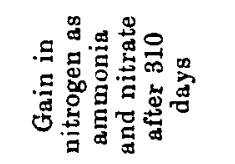 } & 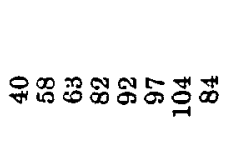 \\
\hline \multirow{6}{*}{\multicolumn{2}{|c|}{ 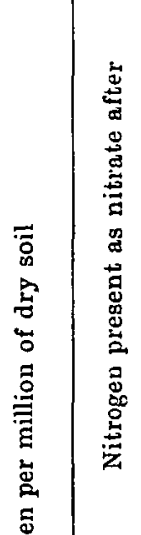 }} & 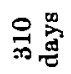 & 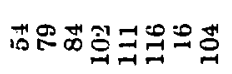 \\
\hline & & 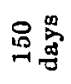 & 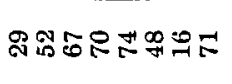 \\
\hline & & จิ & 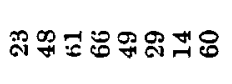 \\
\hline & & ஓ & 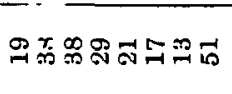 \\
\hline & & 品商 & 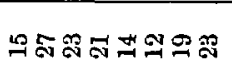 \\
\hline & & 욜 & மニ워쿄 \\
\hline \multirow{6}{*}{ 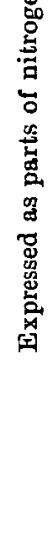 } & \multirow{6}{*}{ 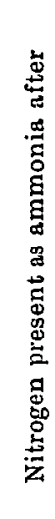 } & 윰 & O \\
\hline & & 品离 & 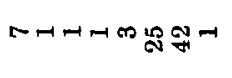 \\
\hline & & 穿兽 & $\exists-\infty \propto ⿻ 上 丨$ \\
\hline & & $8 \underset{0}{\stackrel{m}{6}}$ & 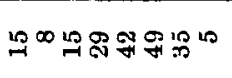 \\
\hline & & 品兽 & 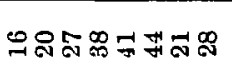 \\
\hline & & 욜 & 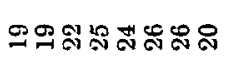 \\
\hline & 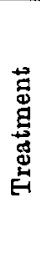 & & 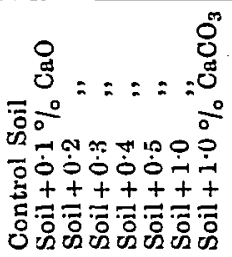 \\
\hline
\end{tabular}


available for plants, within the first $8-9$ months, is approximately 1 per cent. of the caustic lime applied; details are given in the following table, where the difference in ammonia and nitrate content of the untreated and each of the treated soils is given in terms of increments of 0.1 per cent. calcium oxide. The data for the different soils are not for directly comparable periods, but are the final figures obtained in each case, as given in the detailed ammonia and nitrate tables.

TABLE VII. Increments of ammonia and nitrate with various applications of lime.

\begin{tabular}{|c|c|c|c|c|c|c|c|c|c|c|c|c|c|c|c|}
\hline \multirow[b]{2}{*}{ Treatment } & \multicolumn{3}{|c|}{ Rothamsted } & \multicolumn{3}{|c|}{ Millbrook } & \multicolumn{3}{|c|}{ Chelsea } & \multicolumn{3}{|c|}{ Craibstone } & \multicolumn{3}{|c|}{ Woburn } \\
\hline & 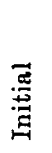 & $\underset{\Xi}{\vec{\Xi}}$ & 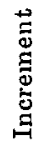 & 永 & 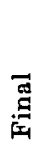 & 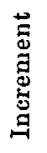 & 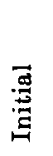 & 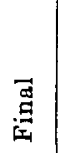 & 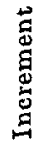 & 要 & 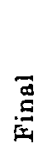 & 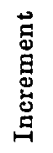 & 怘 & 茎 & 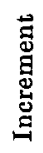 \\
\hline Untreated & 14 & 25 & - & 11 & 15 & - & 73 & 122 & - & 23 & 72 & - & 24 & 64 & - \\
\hline $0.1 \% \mathrm{CnO}$ & 14 & 34 & 9 & 18 & 29 & 14 & 80 & 134 & 12 & 25 & 95 & 23 & 30 & 82 & 18 \\
\hline $0.2 \quad$, & 13 & 57 & 16 & 21 & 40 & 12 & 86 & 139 & 9 & 26 & 100 & 14 & 32 & 87 & 12 \\
\hline & 17 & 52 & 9 & 20 & 43 & 9 & 71 & 153 & 10 & 33 & 104 & 11 & 37 & 106 & 14 \\
\hline & 21 & 56 & 8 & 22 & 51 & 9 & 62 & 157 & 9 & 29 & 119 & 12 & 35 & 116 & 13 \\
\hline & 23 & 61 & 7 & 20 & 59 & 9 & 89 & 172 & 10 & 32 & 140 & 14 & 39 & 121 & 11 \\
\hline & 30 & 106 & 8 & 27 & 60 & 4 & 84 & 189 & 7 & 37 & 214 & 14 & 38 & 128 & 6 \\
\hline $1.0 \% \mathrm{CaO}_{3}$ & 15 & 19 & - & 11 & 22 & 1 & 73 & 117 & - & 28 & 152 & 14 & 29 & 108 & 8 \\
\hline
\end{tabular}

As to the fate of the lime added, fresh evidence will be adduced in a later paper to show that even in soils initially rich in carbonate its reappearance as carbonate is a matter of extreme slowness. Hence the determination of carbonate in a soil recently limed would be quite misleading as to conditions obtaining therein.

\section{Pot Experiments.}

These have been carried out with all except the Woburn soil. The soils were passed through a $3 \mathrm{~mm}$. sieve previous to being filled into glazed earthenware pots (the bottom tubulure of which was corked up in order to prevent loss by drainage), and the amount taken was such as to bring the surface of the soil to within an inch or so from the upper rim of the pot. The weight required consequently varied somewhat with the different soils, $9 \mathrm{~kg}$. of Craibstone soil, $8 \mathrm{~kg}$. of Chelsea 
soil, $10 \mathrm{~kg}$. of Millbrook soil and $10 \mathrm{~kg}$. of Rothamsted soil ${ }^{1}$ being taken. Lime as oxide and carbonate was applied in the same ratio as in the laboratory experiments. The surface soil was then wetted with 100 c.c. of water in order to allow of efficient action of the caustic lime before it became carbonated. Ten barley seeds were sown in each pot, and after about a month the plants were thinned out to five per pot. Equal numbers of the seedlings were weighed to ascertain the initial effect of the lime on plant growth.

\section{Rothamsted Soil.}

The soil was treated on Jan. 15th, 1913, and the barley sown on April 11th; the seedlings were thinned out on May 15th, and the crop, cut on July 1.5th, was slightly, but as far as could be judged, evenly damaged by birds. Germination in all the soils was regular, but at the time of thinning, those plants in soils with 0.1 and 0.2 per cent. calcium oxide were slightly better than those in the control soil. The higher, especially the highest dressings of oxide, appeared to be injuring growth, causing the tips of the leaves to wither.

Table VIII shows the yields of dry produce, etc. A second crop of mustard was then grown in all the pots, and harvested on Oct. 2nd. The yields of dry matter were greatly increased by the applications of small dressings of caustic lime, and reached a maximum with 0.3 per cent. The next higher dressing caused a slight decrease, while the crop growing in soil with 1.0 per cent. oxide was only 14.0 per cent. of that in the control soil. The addition of carbonate was without effect. The second crop, mustard, showed on the whole progressive increases up to the heaviest lime dressing, and carbonate also appeared to cause a slight increase. The production of dry matter in the two crops also increases to the 0.3 per cent. application, and then declines. The percentages of nitrogen in the dry matter increase with the lime dressings, indicating non-nitric nutrition of the plants. The total nitrogen in both crops shows a steady increase, and not a decrease, with higher lime dressings.

1 For this soil results showing the effects of lime on plant growth in pot culture and in the field are available elsewhere. Voelcker, J. A., "Annual Reports of the Consulting Chemist." Journ. Rny. Agric. Soc. 1898-1913.

On account of its stiff clnyey nature the Rothamsted soil was mixed with one-third of its weight of clean sand. The dressings of lime were however calculated on the basis of soil only $1,3,7,5$ Ko. 


\section{Millbrook Suil.}

The pots in this set were put up and the soil treated on March 17th, the barley being sown on May 2nd and afterwards thinned out in the usual way. Germination was good in all cases, with the exception of the heaviest limed soil (Plate IX, figs. 1 and 2). The results are very similar to those described above, except for the greater sensitiveness towards higher doses of caustic lime. A maximum is reached with 0.3 per cent. oxide, while 1.0 per cent. almost checks growth completely. The recovery in the second crop is almost complete, soils with 1.0 per cent. oxide showing a decrease as compared with those receiving the next lower dressing. In some cases the physical condition of the Millbrook soil was altered to such an extent by liming that the seedlings of the first crop were suffering from lack of water, while the soil 10 to 12 inches below was waterlogged.

\section{Craibstone Soil.}

The soil was treated and filled into pots on Jan. 16th and barley sown on April 11th. No differences in germination between the various sets could be detected, and the weights of the seedlings removed at the time of thinning, a month later, show decided increases in weight in all cases as compared with the control. Growth was vigorous throughout, and the crop was cut on July 15th. Progressively increasing yields of dry matter were obtained in all cases in the first and second crop, and the beneficial effect of carbonate is well marked. The magnitude of the crops and the nitrogen content, obtained with dressings of 0.1 to 0.3 per cent. calcium oxide, are very similar to those obtained with carbonate. Comparable results are also found in the case of the second crop.

\section{Chelsea Soil.}

The soil was treated on March 3rd and sown with barley on May 2nd. Germination was quite even, and the weights of seedlings at the time of thinning, on May 27 th, showed slight increases, with the exception of those from soils receiving 1.0 per cent. oxide and 1.0 per cent. carbonate. The crop results are similar to those obtained previously with garden soil ${ }^{1}$ (Plate $X$, figs. 1 and 2). $0 \cdot 2$ per cent. calcium oxide slightly increases the yield, but higher doses tend to decrease it. This is not due to the persistence of caustic lime; indeed lime disappears more rapidly from this soil than from the lighter ones, as is also

1 Hutchinson, loc. cit. p. 327. 


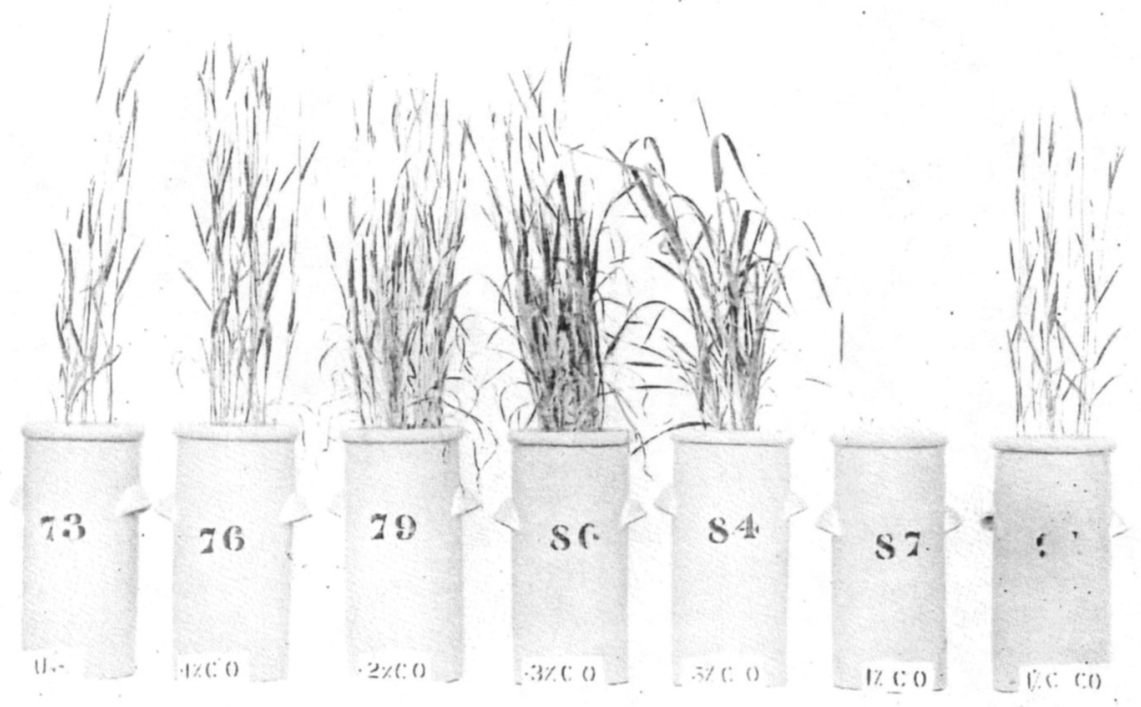

Fig. 1. First crop, Barley.

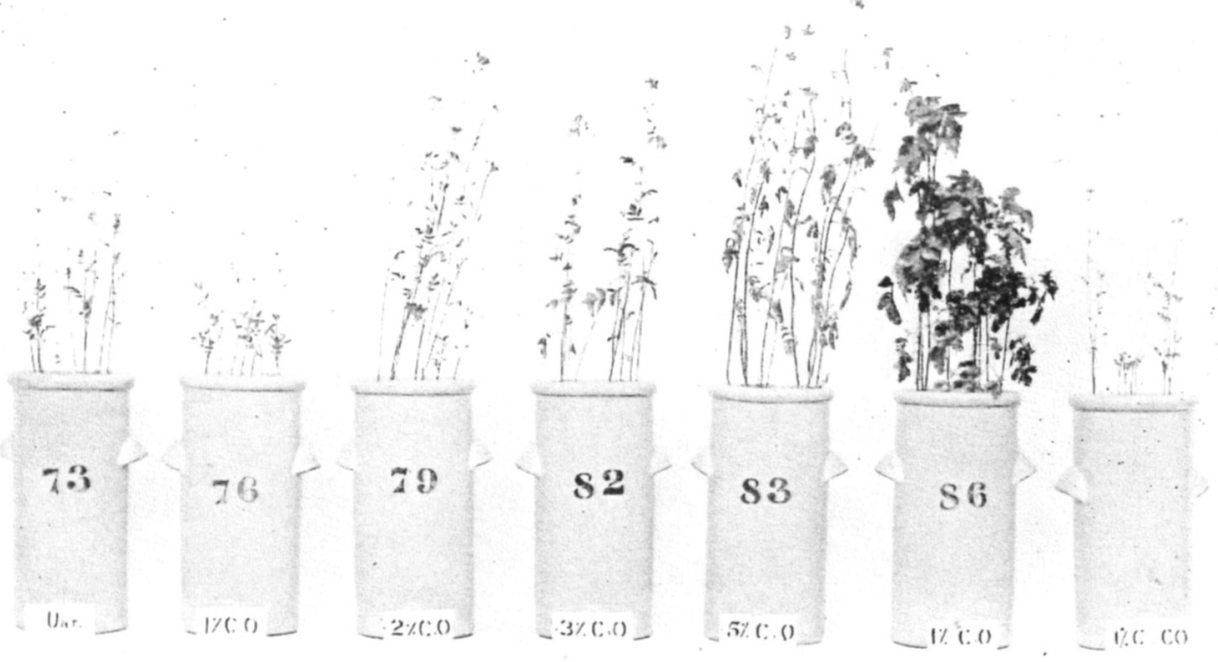

Fig. 2. Second crop, Mustard.

Experiments on the action of Caustic Lime and Carbonate on Millbrook Soil. Treatment (from left to right). Untreated soil, and soil with the addition of $0.1,0.2,0.3,0.5$ and 1.0 per cent. caustic lime and 1.0 per cent. chalk respectively. 


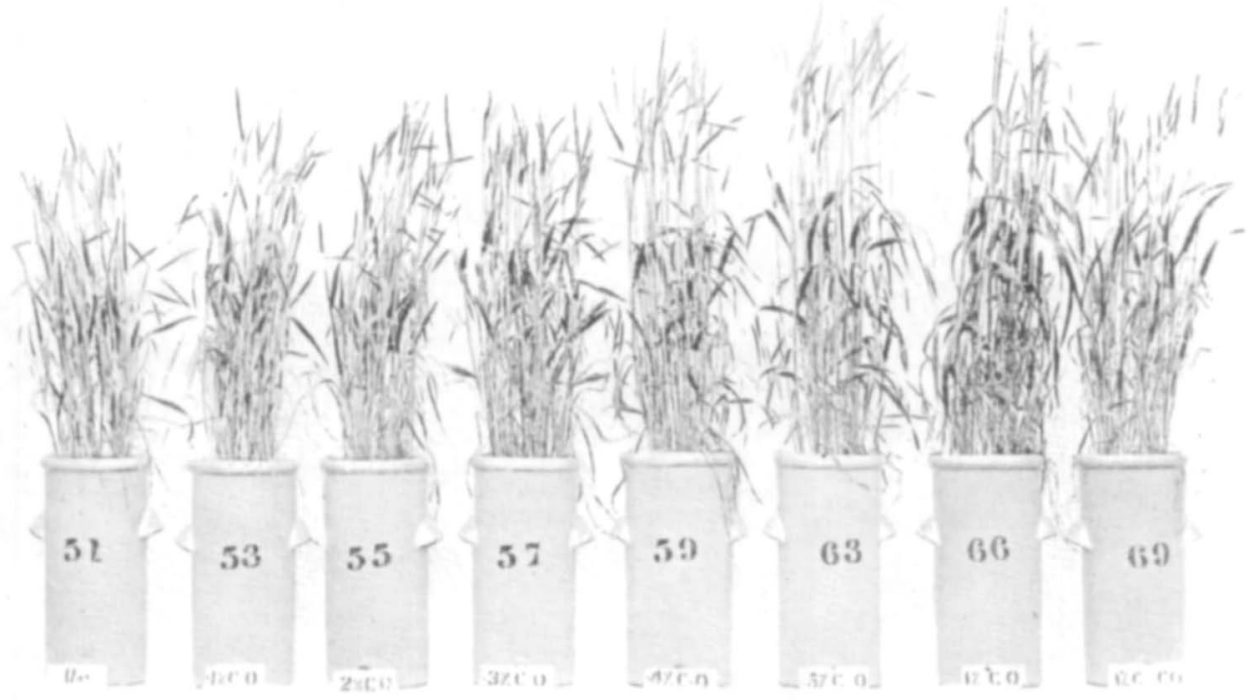

Fig. 1. First crop, Barley.

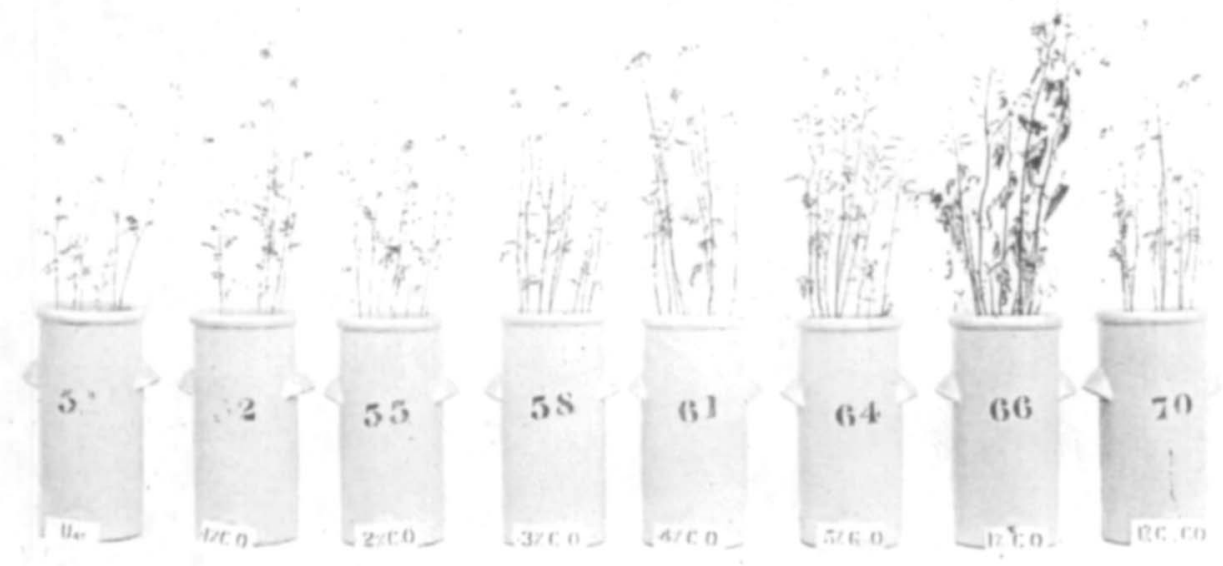

Fig. 2. Second crop, Mustard.

Experiments on the action of Caustic Lime and Carbonate on Chelsea Soil. Treatment (from left to right). Untreated soil, and soil with the addition of $0.1,0.2,0.3 .0 .4,0.5$ and 1.0 per cent. caustic lime and 1.0 per cent. chalk respectively. 
TABLE VIII. Showing the results of pot exporiments with various untreated and limed soils.

\begin{tabular}{|c|c|c|c|c|c|c|c|c|c|c|}
\hline \multirow[b]{2}{*}{ Soil and Treatment } & \multicolumn{4}{|c|}{ 1st crop Barley } & \multicolumn{4}{|c|}{ 2nd crop Mustard } & \multirow{2}{*}{ 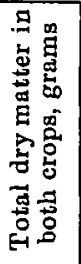 } & \multirow{2}{*}{ 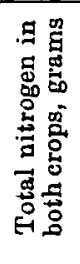 } \\
\hline & 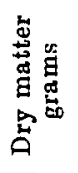 & 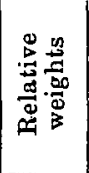 & 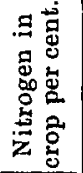 & 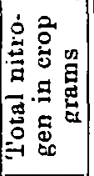 & 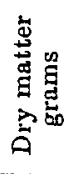 & 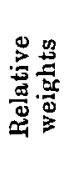 & 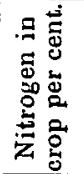 & 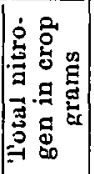 & & \\
\hline \multicolumn{11}{|l|}{ Rothamsted } \\
\hline 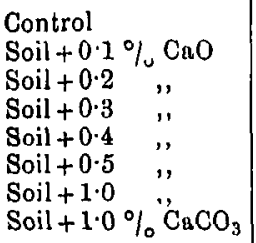 & $\begin{array}{r}7 \cdot 6 \\
15 \cdot 9 \\
17 \cdot 0 \\
22 \cdot 9 \\
20 \cdot 7 \\
15 \cdot 1 \\
1 \cdot 0 \\
7 \cdot 6\end{array}$ & $\begin{array}{r}100 \\
209 \\
224 \\
300 \\
276 \\
199 \\
14 \\
101\end{array}$ & $\begin{array}{l}0.702 \\
0.803 \\
0.925 \\
1.021 \\
1.183 \\
1.802 \\
3.586 \\
0.641\end{array}$ & $\begin{array}{l}0 \cdot 049 \\
0.117 \\
0 \cdot 147 \\
0 \cdot 217 \\
0.227 \\
0 \cdot 253 \\
0.034 \\
0.046\end{array}$ & $\begin{array}{r}1 \cdot 6 \\
1 \cdot 3 \\
2 \cdot 5 \\
3 \cdot 1 \\
4 \cdot 0 \\
7 \cdot 1 \\
17 \cdot 7 \\
1 \cdot 9\end{array}$ & $\begin{array}{r}100 \\
79 \\
155 \\
190 \\
245 \\
435 \\
1086 \\
118\end{array}$ & $\begin{array}{l}1 \cdot 686 \\
1.785 \\
1.570 \\
1.643 \\
1.769 \\
1 \cdot 778 \\
3.206 \\
1.533\end{array}$ & $\begin{array}{l}0.025 \\
0.021 \\
0.037 \\
0.048 \\
0.066 \\
0.119 \\
0.531 \\
0.027\end{array}$ & $\begin{array}{r}9 \cdot 2 \\
17 \cdot 2 \\
19 \cdot 5 \\
26 \cdot 0 \\
24 \cdot 7 \\
22 \cdot 2 \\
18 \cdot 7 \\
9 \cdot 5\end{array}$ & $\begin{array}{l}0.074 \\
0.138 \\
0.184 \\
0.265 \\
0.293 \\
0.372 \\
0.565 \\
0.073\end{array}$ \\
\hline \multicolumn{11}{|l|}{ Millbrook } \\
\hline $\begin{array}{l}\text { Control } \\
\text { Soil }+0.1 \% \mathrm{CaO} \\
\text { Soil }+0.2 \% \\
\text { Soil }+0.3 \quad, \\
\text { Soil }+0.5 \quad ", \\
\text { Soil }+1.0 \% " \\
\text { Soil }+1 \cdot 0 \% \mathrm{CaCO}_{3}\end{array}$ & $\begin{array}{r}8 \cdot 3 \\
15 \cdot 3 \\
19 \cdot 1 \\
22 \cdot 5 \\
7 \cdot 1 \\
0 \cdot 4 \\
9 \cdot 5\end{array}$ & $\begin{array}{c}100 \\
184 \\
230 \\
271 \\
85 \\
1 \cdot 5 \\
114\end{array}$ & $\begin{array}{l}0.826 \\
0.942 \\
1.235 \\
1.523 \\
3.678 \\
4.019 \\
0.831\end{array}$ & $\begin{array}{l}0.065 \\
0.138 \\
0.225 \\
0.327 \\
0.272 \\
0.015 \\
0.074\end{array}$ & $\begin{array}{r}1 \cdot 7 \\
1 \cdot 1 \\
2 \cdot 9 \\
5 \cdot 3 \\
15 \cdot 3 \\
12 \cdot 0 \\
1 \cdot 1\end{array}$ & $\begin{array}{r}100 \\
64 \\
171 \\
306 \\
890 \\
697 \\
64\end{array}$ & $\begin{array}{l}1 \cdot 979 \\
1 \cdot 918 \\
1 \cdot 744 \\
1 \cdot 560 \\
2 \cdot 036 \\
3 \cdot 227 \\
1 \cdot 802\end{array}$ & $\begin{array}{l}0.032 \\
0.020 \\
0.049 \\
0.077 \\
0.295 \\
0.366 \\
0.018\end{array}$ & $\begin{array}{l}10 \cdot 0 \\
16 \cdot 4 \\
22 \cdot 0 \\
27 \cdot 8 \\
22 \cdot 4 \\
12 \cdot 4 \\
10 \cdot 6\end{array}$ & $\begin{array}{l}0.097 \\
0.158 \\
0.274 \\
0.404 \\
0.567 \\
0.381 \\
0.092\end{array}$ \\
\hline \multicolumn{11}{|l|}{ Craibstone } \\
\hline $\begin{array}{l}\text { Control } \\
\text { Soil }+0.1 \%, \mathrm{CnO} \\
\text { Soil }+0.2 \quad ", \\
\text { Soil }+0.3 \quad " \\
\text { Soil }+0.4 \quad " \\
\text { Soil }+0.5 \quad " \\
\text { Soil }+1.0 \quad " \\
\text { Soil }+1.0 \% " \mathrm{CaCO}_{3}\end{array}$ & $\begin{array}{l}28 \cdot 1 \\
27 \cdot 0 \\
30 \cdot 9 \\
32 \cdot 6 \\
37 \cdot 3 \\
37 \cdot 9 \\
45 \cdot 0 \\
33 \cdot 2\end{array}$ & $\begin{array}{r}100 \\
96 \\
110 \\
116 \\
132 \\
135 \\
160 \\
118\end{array}$ & $\begin{array}{l}0.761 \\
0.680 \\
0.652 \\
0.754 \\
0.872 \\
1.014 \\
1.544 \\
0.762\end{array}$ & $\begin{array}{l}0 \cdot 202 \\
0 \cdot 172 \\
0 \cdot 19 \cdot 2 \\
0 \cdot 231 \\
0 \cdot 305 \\
0 \cdot 360 \\
0 \cdot 637 \\
0 \cdot 237\end{array}$ & $\begin{array}{l}1 \cdot 2 \\
1.9 \\
1 \cdot 8 \\
2 \cdot 6 \\
3 \cdot 6 \\
4 \cdot 4 \\
8 \cdot 0 \\
3 \cdot 8\end{array}$ & $\begin{array}{l}100 \\
154 \\
148 \\
210 \\
295 \\
362 \\
654 \\
309\end{array}$ & $\begin{array}{l}2 \cdot 338 \\
1 \cdot 835 \\
2 \cdot 071 \\
2 \cdot 048 \\
2 \cdot 260 \\
2 \cdot 100 \\
2 \cdot 246 \\
1 \cdot 965\end{array}$ & $\begin{array}{l}0.026 \\
0.032 \\
0.036 \\
0.049 \\
0.076 \\
0.087 \\
0.168 \\
0.069\end{array}$ & $\begin{array}{l}29 \cdot 3 \\
28 \cdot 9 \\
32 \cdot 7 \\
35 \cdot 2 \\
40 \cdot 9 \\
42 \cdot 3 \\
53 \cdot 0 \\
37 \cdot 0\end{array}$ & $\begin{array}{l}0.228 \\
0.204 \\
0.228 \\
0.280 \\
0.381 \\
0.447 \\
0.805 \\
0.306\end{array}$ \\
\hline \multicolumn{11}{|l|}{ Chelsen } \\
\hline 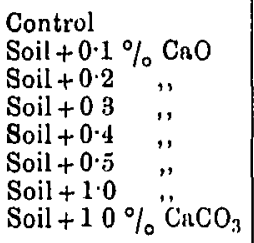 & $\begin{array}{l}34 \cdot 7 \\
34 \cdot 2 \\
39 \cdot 9 \\
39 \cdot 1 \\
38 \cdot 4 \\
36 \cdot 4 \\
32 \cdot 6 \\
33 \cdot 3\end{array}$ & $\begin{array}{r}100 \\
98 \\
115 \\
112 \\
111 \\
105 \\
94 \\
96\end{array}$ & $\begin{array}{l}1 \cdot 242 \\
1 \cdot 192 \\
1 \cdot 254 \\
1 \cdot 398 \\
1 \cdot 689 \\
1 \cdot 989 \\
2 \cdot 495 \\
1 \cdot 061\end{array}$ & $\begin{array}{l}0.405 \\
0.384 \\
0.470 \\
0.509 \\
0.614 \\
0.694 \\
0.668 \\
0.338\end{array}$ & $\begin{array}{r}2 \cdot 9 \\
3.5 \\
3.9 \\
3 \cdot 8 \\
5 \cdot 4 \\
6 \cdot 7 \\
16.5 \\
3.5\end{array}$ & $\begin{array}{l}100 \\
122 \\
135 \\
133 \\
190 \\
234 \\
572 \\
122\end{array}$ & $\begin{array}{l}1.855 \\
1.783 \\
1.784 \\
1.812 \\
1.655 \\
1.722 \\
2.307 \\
1.659\end{array}$ & $\begin{array}{l}0.050 \\
0.057 \\
0.066 \\
0.064 \\
0.084 \\
0.108 \\
0.364 \\
0.054\end{array}$ & $\begin{array}{l}37 \cdot 6 \\
37 \cdot 7 \\
43 \cdot 8 \\
42 \cdot 9 \\
43 \cdot 8 \\
43 \cdot 1 \\
49 \cdot 1 \\
36 \cdot 8\end{array}$ & $\begin{array}{l}0.455 \\
0.441 \\
0.536 \\
0.573 \\
0.698 \\
0.802 \\
1.032 \\
0.392\end{array}$ \\
\hline
\end{tabular}


indicated by the relatively short period during which nitrification is inhibited. The ammonia and nitrate figures show a steady increase with these doses, so that the crop depression appears to be a physiological effect on the plant rather than a shortage of food ${ }^{1}$. Throughout the period of growth of the first crop, the barley plants appeared very flaccid in character; this effect was also evident in the third crop which was rye.

The second crop, mustard, does not show this effect, but gives a steady rise with increasing lime applications. In general, there is no such increased nitrogen content in plants growing in these limed soils, as was observed with the Rothamsted and Millbrook soils.

\section{SUMmaRY.}

Caustic lime is found to have two distinct effects on the soil:

1. A partial sterilisation effect,

2. A chemical action, decomposing some of the soil organic matter.

The amount of caustic lime necessary to induce specific changes in the flora and fauna of the soil depends very largely on the character of the soil. The light sandy Millbrook soil, poor in organic matter and in carbonate, reacted sharply with 0.2 to 0.3 per cent. caustic lime; the Rothamsted clay soil, poor in organic matter but rich in carbonate, was found to react to 0.3 to 0.4 per cent.; the acid Woburn soil required an amount between 0.5 and 1.0 per cent., as did also the rich Chelsea garden soil, which already contained carbonate; the Craibstone soil, with a high organic and a low carbonate content, failed to react even to applications of 1.0 per cent. caustic lime.

Each of these soils, as well as many others examined, appears to absorb directly a definite amount of caustic lime, and until these requirements are fully satisfied the partial sterilisation phenomena do not set in. These phenomena include a sudden initial decrease and subsequent increase in the numbers of bacteria, the extinction of the larger forms of protozoa and the inhibition of nitrate production. Lower doses than those required for partial sterilisation induce a temporary suspension of nitrification, and consequent accumulation of ammonia, for periods varying with the amount of lime and the character of each soil; they also lead to a temporary increase in numbers of

1 In a parallel case of peaty soils Ritter (17) suggested that the injurious effect occasionally obtained on liming may be due to oxalic acid produced, and Densch (18) suggests a reduction of nitrates to nitrites. 
bacteria capable of growing on gelatine plates, but these afterwards decrease until the level of the untreated soil is reached.

Caustic lime chemically breaks down some of the organic matter of the soil, as shown by the ammonia formed during periods when soil bacteria are quiescent; when, however, bacterial growth commences, there is a large increase in the rate of ammonia production.

The return in nitrogen, as ammonia and nitrate for each increment of lime applied, varies with the character and reaction of the soil and the carbonate content. On the average, and within a period of about 250 days, it amounted approximately to 1.0 per cent. by weight of the caustic lime applied. Carbonate gave less returns, apparently because of its relative inaction on soil organic matter.

The pot experiments show amounts of available nitrogen in the soils comparable with the amounts of ammonia and nitrate produced in the laboratory experiments. In some cases the amount of caustic lime applied was sufficiently large to check the growth of bacteria and to depress plant growth in the first crop', but in the case of the Chelsea soil the bacteria were active but plant growth was depressed, a phenomenon not yet satisfactorily explained.

As in other experiments, inhibition of nitrification resulting from applications of lime leads to a higher nitrogen content in the plants. This has been ascribed to the assimilation of nitrogen compounds other than nitrates, and, if occurring to any extent, involves an uneconomic utilisation of soil nitrogen. Where the amount of lime does not check nitrification, as in the case of the lighter dressings to the Craibstone soil, the nitrogen content of the plants is about the normal.

1 A certain agreement exists between maximum yields of first crop with applications of caustic lime sufficient to induce partial sterilisation (e.g. Millbrook aud Rothamsted soils). 


\section{BIBLIOGRAPHY.}

1. Hutchinson, This Journal, 1913, 5, 320.

2. Scrolze, Chemie fiir Landwirte, 1846, 1, 677.

3. Peterson, Landw. Versuch. Stat., 1871, 13, 160.

4. Ebermayer, Forsch. Agrik. Phys., 1890, 15.

5. Hilgard, ibid., 1892, 400.

6. Weegler, Sargent and Hartwell, Journ. Amer. Chem. Soc., 1899, 21, 1032.

7. Chester, Rep. Delaware Exp. Stat. 1901, 50.

8. Fabricios and von Feilitzen, Svenska Mosskulturför. Tidskr., 1905, 19, 84. -, Cent. Bakt. Par., II, 1905, 14, 161.

9. Engberding, Cent. Bakt. Par., ir, 23,603.

10. FISCeER, Landw. Jahrb., 1909, 38, 358. Landw. Vers. Stat., 1909, 70, 335.

11. WoLf, Landw. Jahvb., 1882, 11, 411.

12. Jenkins and Britton, Conn. Stat. Rep. 1899, 211.

13. Withers and Fraps, Journ. Amer. Chem. Soc., 1902, 24, 528.

14. Wohltmann, Fischer and Schneider, Joum. Landw. 1904, 52, 97.

15. Christensen and Larsen, Cent. Bakt. Par., II, 1911, 29, 347.

16. KRÜGER, Diss. Königsberg, 1908.

" Ehrenberg, Landw. Jahrb., 1904, 33, 15.

" Lipman and Brown, New Jersey Exp. Stat. Rep. 1907.

" Brown, Cent. Bakt. Par., II, 1912, 35, 234.

17. Ritter, Bied. Zentr., 1913, 42, 239.

18. DeNsch, Landvo. Jahrb., 1913, 44, 331. 